\title{
Kualitas Ikan Malalugis (Decapterus kurroides) Presto pada Beberapa Hari Penyimpanan
}

\author{
Magdalena F. Sidabutara*, Feti Fatimaha, Johnly A. Roronga \\ aJurusan Kimia, FMIPA, Unsrat, Manado
}

\section{K A T A K U N C I}

Ikan malalugis

Presto

Daya simpan

\section{K E Y W O R D S}

Malalugis Fish

Presto

Stored Capacity

AVAILABLE ONLINE

10 Februari 2013

\begin{abstract}
A B S T R A K
Telah dilakukan penelitian untuk mengetahui kualitas dari pengolahan ikan malalugis presto dengan perlakuan pemberian bumbu maupun tanpa bumbu selama beberapa hari penyimpanan pada suhu $5^{\circ} \mathrm{C}$. Ikan malalugis (Decapterus kurroides) adalah salah satu sumber daya perikanan yang memiliki nilai ekonomis tinggi karena dagingnya memiliki cita rasa yang baik dan banyak digemari oleh masyarakat. Presto merupakan suatu teknik olahan yang dapat menghasilkan produk berduri lunak. Parameter uji yang dilakukan untuk menganalisis kualitas ikan malalugis presto adalah kadar protein, kadar air, kadar malondialdehid (MDA), dan Total Plate Count (TPC). Hasil penelitian ikan malalugis presto pada perlakuan pemberian bumbu maupun tanpa bumbu, menunjukan kadar protein mengalami peningkatan setelah proses presto. Kadar air dan TPC untuk ikan yang dibumbui dan tanpa bumbu, belum melebihi standar mutu. Kadar MDA pada pelakuan dibumbui atau tanpa bumbu menunjukkan hasil yang melebihi standar mutu.
\end{abstract}

A B S T R A C T

Research have been done to know the quality from processing of malalugis fish presto with and without seasoning during for several days of depository at $5^{\circ} \mathrm{C}$. Malalugis fish (Decapterus kurroides) is one of fishery resources which have high economy value because the meat had a good taste and many of the people loved that. Presto is a processing technique which to produce a soft-bone product. Parameter of test to analyze the quality of malalugis fish presto was content of protein, water, malondialdehyde (MDA) and Total Plate Count (TPC). Research result for malalugis fish presto with or without seasoning, showed decreasing of protein content after presto process. Water content and TPC for fish with and without seasoning on cold temperature $\left(5^{\circ} \mathrm{C}\right)$ have not exceed of quality standard. MDA content of seasoning and without seasoning showed the result which have exceed of quality standard.

\begin{abstract}
1. Pendahuluan
Indonesia merupakan negara maritim yang kaya akan sumber daya alam dan memiliki potensi yang besar dalam bidang perikanan, namun hasil-hasil dari sumber daya alam tersebut belum sepenuhnya dimanfaatkan secara maksimal oleh masyarakat Indonesia. Seiring dengan meningkatnya kebutuhan pangan, dikembangkan teknologi yang dapat mengolah hasil tangkapan laut ini menjadi suatu produk yang digemari oleh para konsumen.
\end{abstract}

Pada ilmu kimia bahan pangan dikembangkan suatu teknologi pangan yang merupakan aplikasi dari ilmu pangan berupa sortasi, pengawetan, pemrosesan, pengemasan, distribusi, hingga penggunaan bahan pangan yang aman dan bernutrisi (Suryana, 2012). Salah satu teknik penanganan dalam pengolahan bahan pangan ikan yaitu produk olahan presto ikan. Presto ikan adalah bentuk pengolahan ikan dengan garam dan bumbu serta melalui suatu proses dengan pemanasan dan tekanan. Alat yang digunakan dalam skala rumah 
tangga disebut dengan panci presto (alat presto). Produk presto menarik perhatian khusus yaitu semua bagian ikan termasuk tulangnya dapat dikonsumsi (Tapotubun et al., 2008).

Prinsip pengolahan presto ikan tidak jauh berbeda dengan proses perendaman atau pemindangan dengan garam, perbedaan hanya pada pemberian bumbu-bumbu masakan, suhu dan tekanan yang digunakan (Arifudin, 1993). Bumbubumbu masakan berperan sebagai pemberian aroma dan penentu cita rasa, dan dapat bermanfaat sebagai pengawet yang dapat membunuh bakteri (Fachruddin, 1997). Solarbesain (2005), menyatakan semua jenis ikan dapat diolah menjadi duri lunak dengan cara memperhatikan waktu pemanasan yang tepat agar dihasilkan produk presto dengan kualitas yang baik.

Sulawesi Utara merupakan salah satu wilayah perairan penghasil ikan malalugis atau yang dikenal dengan sebutan ikan layang anggur. Ikan Malalugis (Decapterus kurroides, Bleeker,1855) merupakan salah satu hasil terpenting dari sumber daya perikanan dan memiliki nilai ekonomis yang tinggi karena selain dagingnya memiliki tekstur yang kompak, citarasa dari ikan ini juga banyak digemari masyarakat sehingga dapat menjadi salah satu sumber pemenuhan kebutuhan protein hewani (Prihartini, 2006).

Tapotubun et al. (2008) melakukan penelitian dalam menentukan waktu pemanasan yang tepat agar diperoleh produk olahan presto yang baik pada beberapa jenis ikan yang salah satunya merupakan ikan layang atau malalugis, akan tetapi belum dilakukannya pengujian kualitas produk olahan ikan malalugis presto selama beberapa hari penyimpanan. Pada penelitian ini dilakukan analisis produk olahan presto untuk mengetahui kualitas ikan presto.

\section{Metode}

\subsection{Bahan dan Alat}

Bahan-bahan yang digunakan dalam penelitian ini adalah ikan malalugis (Decapterus kurroides) segar, bumbu-bumbu masakan seperti bawang merah, bawang putih, cabe, kemiri, lengkuas, bahan penyedap masakan, daun salam, sereh, dan asam jawa yang diperoleh dari pasar modern Multi Mart Manado dan air mineral. Bahan kimia berkualitas analytical grade yang digunakan adalah aquades, selenium, asam sulfat pekat, asam borat $2 \%$, asam klorida 0,01 N, etanol 95\%, natrium hidroksida 30\%, natrium klorida, Phenolphtalein (PP), trikloroasetat (TCA) $10 \%$, asam tiobarbiturat (TBA) $1 \%$ dan Plate Count Agar (PCA).

Alat yang digunakan adalah papan pengalas, alat pemotong ikan, neraca digital, alat pencampur (blender), alat presto, alat pengukur waktu (stopwatch), wadah, tempat sampel uji, alat-alat gelas, seperangkat alat titrasi, cawan porselin, botol serum, pipet mikro, alat pemanas (oven), desikator, waterbath, sentrifus (centrifuge), autoclave, lemari pendingin, labu kjeldahl, alat pengaduk (vortex), batang pengaduk, pipet volumentrik, spektrofotometer UV-Vis, cawan hitung dan inkubator.

\subsection{Pembuatan Ikan Malalugis Presto (Tapotubun et} al., 2008)

Ikan malalugis disiangi, dicuci dan ditimbang kemudian direndam dengan larutan garam 3\% selama 15 menit lalu dicuci dan ditiriskan. Setelah itu direndam lagi dalam larutan garam jenuh (20\%) selama 15 menit kemudian dilaburi bumbu yang telah dihaluskan (bawang merah 4,4\%, bawang putih 0,5\%, cabe $0,5 \%$, kemiri $4,4 \%$, lengkuas $0,5 \%$, bahan penyedap masakan 0,3\%, daun salam, sereh, dan asam jawa). Setelah dilaburi bumbu, dilakukan pemanasan dengan cara direbus dalam panci presto dengan air sebanyak 1 liter selama 60 menit. Dibuat ke dalam dua bentuk perlakuan. Perlakuan yang pertama ikan segar tanpa pemberian bumbu, dan perlakuan kedua dengan pemberian bumbu. Tahap berikutnya, sampel ikan malalugis diletakan ditempat sampel uji selama 3 hari dan diuji karakteristiknya secara berkala yang meliputi uji kadar air, kadar protein, kadar MDA dan TPC.

\subsection{Uji Kadar Protein dengan Metode Kjeldahl (SNI - 2891 - 1992).}

Ditimbang 0,51 g contoh dan dimasukkan ke dalam labu kjeldhal 100 ml. Larutan ditambahkan dengan campuran $2 \mathrm{~g}$ selenium dan $25 \mathrm{ml}$ asam sulfat pekat. Dekstruksi hingga larutan hijau jernih. Larutan dibiarkan dingin lalu diencerkan dan dimasukkan ke dalam labu ukur $100 \mathrm{ml}$ yang ditempatkan sampai tanda garis. Dipipet $5 \mathrm{ml}$ larutan dan dimasukkan ke dalam alat penyuling dan ditambahkan $5 \mathrm{ml}$ natrium hidroksida 30\% dan beberapa tetes indikator PP. Disuling selama 10 menit dan ditampung pada $10 \mathrm{ml}$ larutan asam borat $2 \%$ yang telah dicampur dengan indikator. Ujung pendingin kemudian dibilas dengan air suling, lalu dititrasi dengan asam klorida 0,01 N, dan blanko dibuat.

\subsection{Uji Kadar Air dengan Metode Oven (Apriyantono et al., 1989).}

Cawan kosong dikeringkan dalam oven (suhu $105^{\circ} \mathrm{C}$ ) selama 60 menit dan dinginkan dalam desikator selama 30 menit, kemudian 5 gram sampel yang sudah dihomogenkan dalam cawan ditimbang dengan cepat kemudian tempatkan cawan beserta isinya di dalam oven (suhu $105^{\circ} \mathrm{C}$ ) selama 3 jam. Dihindari kontak antara cawan dengan dinding oven. Cawan dipindahkan ke desikator, lalu dinginkan. Setelah dingin ditimbang kembali dan dikeringkan ke dalam oven sampai diperoleh berat yang tetap.

Menurut SNI (01-3182-1992), perhitungan kadar air sebagai berikut :

$$
\% \text { air }=\frac{m_{0}-m_{1}}{m_{0}} \times 100 \%
$$

keterangan: $m_{0}=$ berat cuplikan mula-mula (g); $m_{1}=$ berat cuplikan setelah dikeringkan (g) 


\subsection{Analisis MDA (Malondialdehid) dengan pereaksi TBA (Thiobarbituric Acid) (Shahidi dan Hong, 1991).}

Sebanyak 0,5 gram sampel ikan ditimbang dan ditambahkan dengan $4 \mathrm{ml}$ asam trikloroasetat (TCA) $10 \%$ disentrifuse selama 10 menit. Supernatant diambil dan ditambahkan dengan 2,5 $\mathrm{ml}$ asam tiobarbiturat (TBA) $1 \%$ kemudian larutan dicampur homogen dengan dipanaskan di waterbath selama 10 menit lalu didinginkan. Fitrat yang berwarna merah muda selanjutnya diukur absorbansinya pada panjang gelombang $532 \mathrm{~nm}$ menggunakan spektrofotometer UV-Vis. Kadar MDA dihitung dengan menggunakan kurva baku standar dari tetraetoksipropana (TEP) sebagai prekursor MDA.

\subsection{Uji TPC (Total Plate Count) (Fardiaz, 1992).}

Uji TPC dilakukan untuk mengetahui kandungan koloni mikrobiologi dalam sampel. Alat dan bahan yang akan digunakan seperti Erlenmeyer, botol serum, pipet mikro,dan media agar sebelumnya dilakukan sterilisasi selama 15 menit di dalam autoclave. Media yang digunakan adalah Plate Count Agar (PCA).

Suspensi contoh dilakukan dengan pengenceran $10^{-1}$ dengan menghancurkan 1 gram sampel ke dalam $9 \mathrm{ml}$ larutan pengencer $(\mathrm{NaCl})$. Suspensi bahan $1 \mathrm{ml}$ dimasukkan ke dalam $9 \mathrm{ml}$ larutan pengencer untuk mendapatkan pengenceran yang diinginkan. Suspensi yang telah ada dicampurkan dengan media agar dan kemudian koloni bakteri dapat dihitung setelah inkubasi selama 2 hari pada suhu $30^{\circ} \mathrm{C}$. Jumlah koloni yang diterima 25-250 koloni per cawan. Nilai TPC dapat dihitung dengan menggunakan rumus:

$$
\mathrm{TPC}=\text { Jumlah koloni per cawan } \mathrm{x} \frac{1}{\text { Faktor pengencer }}
$$

\section{Hasil dan Pembahasan \\ 3.1. Kadar Protein}

Pengujian kadar protein menggunakan metode kjedahl dilakukan untuk menganalisis kadar protein kasar pada bahan makanan berdasarkan kadar nitrogen (Winarno, 1986). Hasil pengujian kadar protein pada ikan malalugis presto dapat dilihat pada Gambar 1.

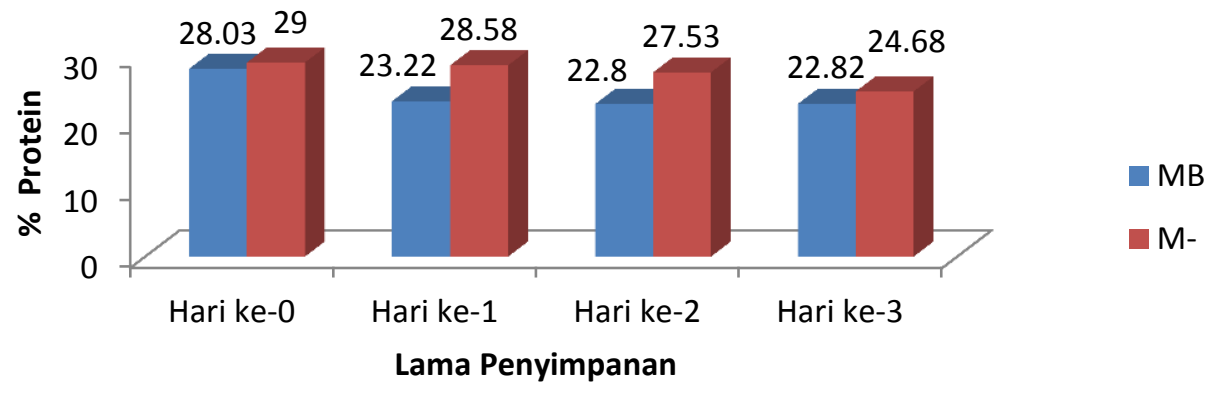

Gambar 1 - Kadar Protein Ikan Malalugis Presto (Keterangan, MB : Malalugis dengan Bumbu, M- Malalugis Tanpa Bumbu).

Berdasarkan data pada Gambar 1, kandungan protein pada sampel ikan malalugis presto tanpa bumbu dan dengan pemberian bumbu menunjukan hasil persentasi yang stabil. Ikan layang segar umumnya memiliki kandungan protein sebesar 22\% (Irianto et.al., 2007). Jika dibandingkan dengan hasil analisis yang dilakukan, persentase kadar protein menunjukan kandungan protein yang lebih tinggi setelah dilakukan proses pengolahan. Pada proses presto terjadi pengeluaran air dari daging ikan yang menyebabkan protein lebih terkonsentrasi jika dibandingkan dengan ikan segar. Semakin tinggi persentasi kadar protein, kemampuan mengikat air semakin kecil dan daya simpan bahan pangan semakin tidak baik. Hal ini diduga karena proses pengolahan ikan dengan cara dipanaskan (direbus) dengan batas waktu maksimum agar duri dari ikan malalugis tersebut lunak dan tekstur ikan tetap kompak. Pada penyimpanan selama beberapa hari, produk ikan malalugis pada beberapa perlakuan menunjukan penurunan tingkatan kadar protein pada ikan seiring dengan lama penyimpanan ikan tersebut.

\subsection{Kadar Air}

Berdasarkan analisis yang dilakukan, kadar air yang diperoleh dari hasil penelitian dengan perlakuan penambahan bumbu dan tanpa bumbu dapat dilihat pada Gambar 2.

Berdasarkan data pada Gambar 2 menunjukan hasil yang tidak stabil antara ikan yang diolah dengan bumbu maupun tanpa bumbu. Pada ikan malalugis tanpa bumbu, dari hari ke-0 hingga ke-2 mengalami penurunan dan kembali meningkat pada hari yang ke3. Menurut Barrett et.al. (1998) penurunan kadar air pada suhu rendah akan meningkatkan proporsi padatan sehingga tekstrur menjadi mengeras. Selain itu, sampel yang disimpan pada suhu rendah dapat menyerap air dilingkungan sekitar penyimpanan sehingga nilai kadar air pada hari ketiga dapat meningkat. 
Perlakuan penambahan bumbu memiliki kadar air yang lebih tinggi dibandingkan dengan ikan yang tidak dilumuri bumbu. Hal ini dapat dipengaruhi oleh bumbu yang memiliki sifat mudah menguap apabila menggunakan metode oven yang salah satunya adalah lengkuas. Lengkuas diketahui memiliki senyawa volatil yang dapat menguap bersama dengan air apabila dipanaskan pada suhu yang tinggi $\left(105^{\circ} \mathrm{C}\right)$ dan dapat mempengaruhi nilai kadar air pada ikan sehingga selisih berat sampel ikan menjadi lebih besar. Sesuai dengan SNI 01-3182-1992, prinsip metoda dalam penentuan kadar air pada suatu bahan yang dipanaskan pada suhu $100^{\circ} \mathrm{C}-105^{\circ} \mathrm{C}$, dapat menyebabkan hilangnya air dan zat-zat menguap lainnya, sehingga kekurangan berat tersebut dianggap sebagai berat air. Menurut Buckle et.al. (1987), kadar air memiliki pengaruh khusus dalam penentuan daya awet suatu bahan. Semakin tinggi kadar air dalam suatu bahan pangan, daya simpan serta kualitas bahan pangan tersebut semakin rendah. Kadar air ikan malalugis presto dari semua perlakuan dan penyimpanan sampai hari ke-3 belum melewati batas mutu yang ada. Standar mutu kadar air untuk produk perikanan adalah 60 - 70\% (Arpah, 1993).

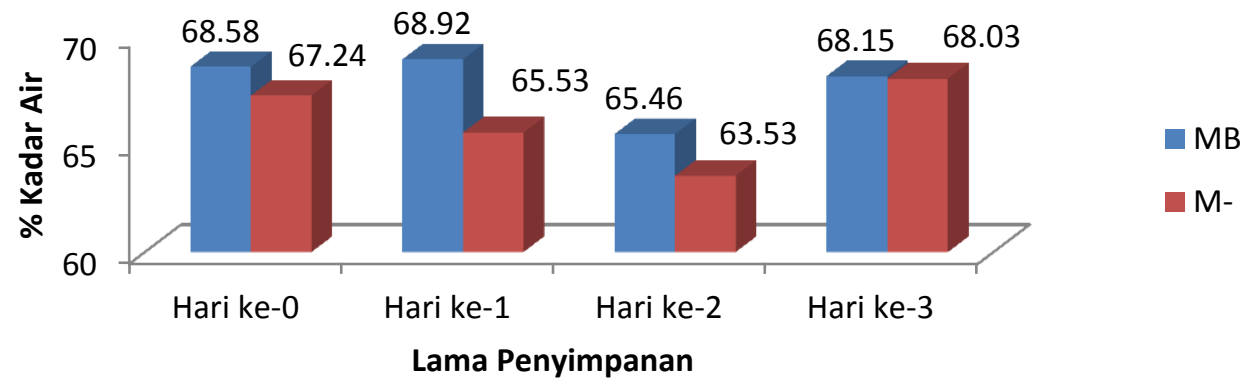

Gambar 2 - Kadar Air Ikan Malalugis Presto (Keterangan, MB : Malalugis dengan Bumbu, M- : Malalugis Tanpa Bumbu)

\subsection{Analisis Kadar Malondialdehid (MDA) dengan Menggunakan Pereaksi Thiobarbituric Acid (TBA)}

Tingkat kerusakan suatu bahan pangan dapat diketahui dengan analisis MDA. Kadar MDA $(\mu \mathrm{M})$ pada ikan yang malalugis presto dengan bumbu maupun tanpa bumbu dapat dilihat pada Gambar 3.

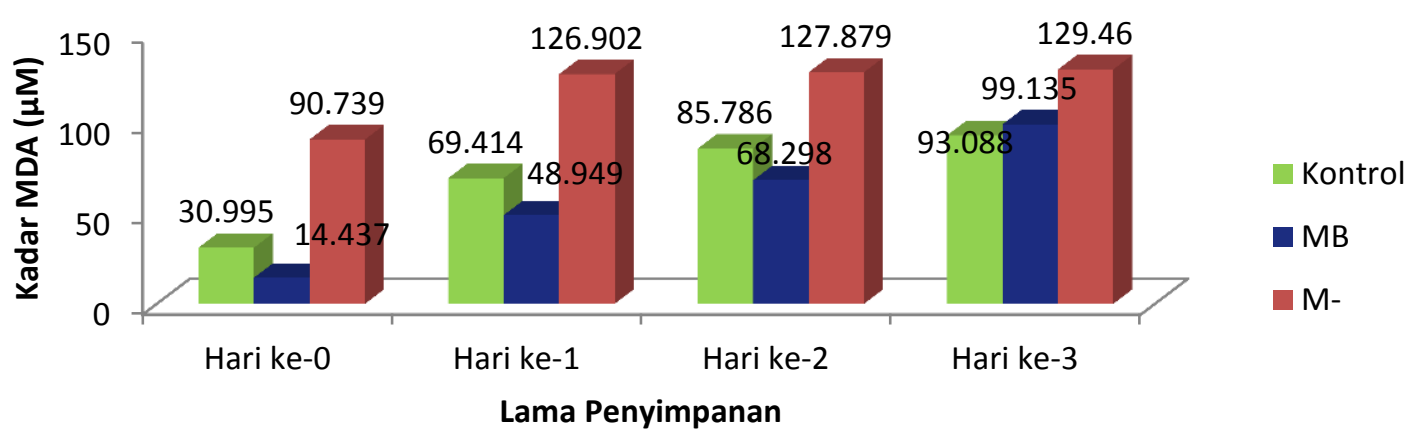

Gambar 3 - Kadar MDA Ikan Malalugis Presto (Keterangan, MB : Malalugis dengan Bumbu, M- : Malalugis Tanpa Bumbu).

Berdasarkan data pada Gambar 3, kadar MDA semakin meningkat seiring dengan lama penyimpanan. Nilai TBA sangat tinggi yang dikarenakan produk olahan diduga mengalami kerusakan pada proses pemasakan ikan. Pada perbandingan hasil olahan ikan tanpa pemberian bumbu dan dengan diberi bumbu, menunjukan angka TBA ikan yang dibumbui lebih rendah jika dibandingkan dengan tanpa pemberian bumbu. Bumbu-bumbu yang dilumuri pada ikan rata-rata mengandung antioksidan yang dapat menghambat ketengikan seperti yang terdapat pada bawang putih, bawang merah, cabai serta bumbu lain yang digunakan pada pengolahan ikan presto ini (Kurniawati, 2010). Suhu juga dapat mempengaruhi angka TBA pada sampel. Pada suhu rendah $\left(5^{\circ} \mathrm{C}\right)$, proses oksidasi dapat dihambat.

Peningkatan nilai TBA menunjukan selama waktu penyimpanan telah terjadi degradasi atau kerusakan lemak yang menghasilkan senyawa manoldehida. 
Apabila diamati secara fisik, nilai TBA yang terlampau tinggi dapat dilihat pada warna merah muda yang pekat. Ditinjau dari batas mutu kadar TBA, nilai yang melebihi $10 \mu \mathrm{M} \mathrm{MDA} / \mathrm{kg}$ sampel daging dianggap tengik dan memiliki kualitas yang tidak baik (Ke dan Ackman, 1976).

\subsection{Total Plate Count (TPC)}

Pada hasil penelitian uji TPC, data yang diperoleh ditunjukan pada Gambar 4.

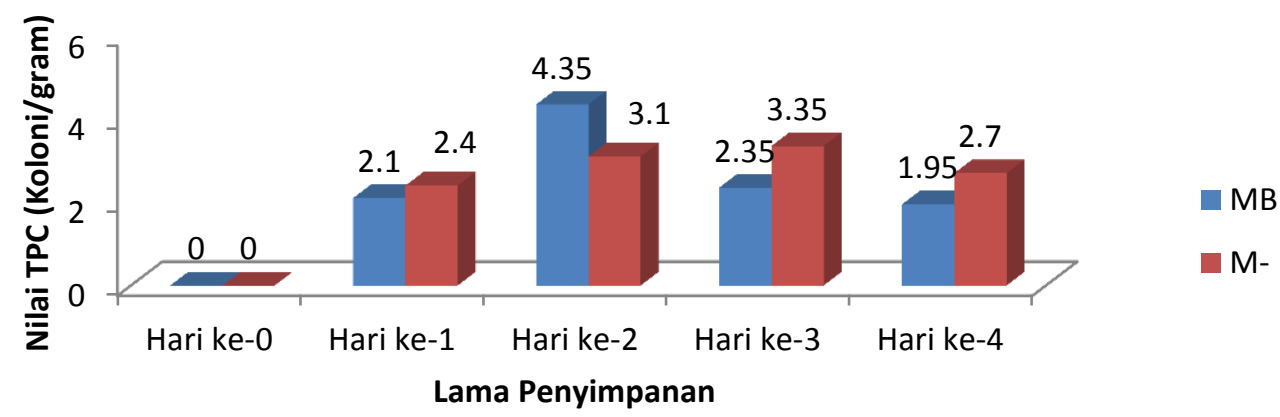

Gambar 4 - Hasil uji TPC (Keterangan, MB : Malalugis dengan Bumbu, M- : Malalugis Tanpa Bumbu).

Berdasarkan data pada Gambar 4, hasil pada tiap perlakuan tidak stabil. Ikan malalugis dengan penambahan bumbu meningkat pada hari ke-2 dan menurun pada hari ke-3 dan 4. Sama halnya pada perlakuan tanpa bumbu, TPC terus meningkat hingga hari ke-3 dan menurun pada hari yang ke-4.

Penyimpanan pada suhu rendah dapat membuat produk olahan bertahan lebih lama dan kandungan koloni bakteri lebih sedikit. Menurut SNI (01-2729.32006), penyimpanan produk pangan dalam lemari pendingin ditujukan untuk mencegah terjadinya kemunduran mutu dan kontaminasi bakteri. Hal ini dikarenakan terdapat bakteri yang tidak dapat bertumbuh dengan baik pada suhu rendah Pada penyimpanan suhu rendah yaitu jumlah koloni bakteri masih dibawah batas maksimum dan dapat dikonsumsi hingga penyimpanan 3 hari (apabila ditinjau dari mutu standar nasional pada cemaran mikroba pada bahan pangan).

Pemberian bumbu pada ikan malalugis presto hanya memberikan efek berkurangnya jumlah koloni bakteri dikarenakan bumbu dan garam yang diaplikasikan pada produk olahan presto dapat membantu menghambat pertumbuhan bakteri karena memiliki senyawa antioksidan dan antimikroba (Purba dan Rusmarilin, 2006).

\section{Kesimpulan}

Ikan malalugis presto yang diolah dengan penambahan bumbu dan tanpa bumbu menunjukan kualitas yang cukup baik pada penyimpanan suhu $5^{\circ} \mathrm{C}$. Kadar protein mengalami peningkatan setelah proses presto. Kadar air dan TPC untuk ikan yang dibumbui dan tanpa bumbu, pada suhu rendah belum melebihi standar mutu. Kadar MDA pada pelakuan dibumbui atau tanpa bumbu menunjukkan hasil yang melebihi standar mutu.

\section{Daftar Pustaka}

Apriyantono, A., D. Fardiaz, N. L. Puspitasari, Sedarnawati, dan S. Budiyanto. 1989. Pentunjuk Laboratorium Analisis Pangan. Bogor : Institut Pertanian Bogor (IPB Press).

Arifudin, R. 1993. Bandeng Presto, Kumpulan HasilHasil Penelitian Pascapanen Perikanan. Jakarta : Pusat Penelitian dan Pengembangan Perikanan.

Arpah, M. 1993. Pengawasan Mutu Pangan. Penerbit Tarsito, Bandung

Barrett, A., B. Jack, R. Mhicelle and R. Timoty. 1998. Texture and Storage Stability of Process Beefstick as Affected by Glycerol and Moisture Levels. Journal of food science. 63:84-87.

Bleeker. 1855. Decapterus kurroides. ITIS Report, TSN 168733.

Buckle, K. A., A. R. Edwards, G. H. Fleet and M. Wooton. 1987. Ilmu Pangan. Terjemah H. Purnomo dan Adiono. Jakarta : Universitas Indonesia (UIPress).

Fachruddin, L. 1997. Membuat Aneka Abon. Yogyakarta : Kanisius.

Fardiaz, S. 1992. Mikrobiologi Pangan. Jakarta : Gramedia.

Irianto, H. E., dan I. Soesilo. 2007. Dukungan Teknologi Penyediaan Produk Perikanan. Makalah pada Seminar Nasional Hari Pangan Sedunia. Bogor : Badan Riset Kelautan dan Perikanan, Departemen Kelautan dan Perikanan.

Ke, P.J., dan R.G.Ackman. 1976. Metal-catalysed oxidation in mackerel skin and meat lipids. J. Am. Oil Chem.Soc. 53: 636-640. 
Kurniawati, N. 2010. Sehat Alami dan Cantik Berkat Khasiat Bumbu Dapur. Bandung: Qanita.

Prihartini, A. 2006. Analisis Tampilan Biologis Ikan Layang (Decapterus spp) Hasil Tangkap Purse Seine yang Didaratkan di PPN Pekalongan. [TESIS]. Universitas Diponegoro, Semarang.

Purba, A. dan H. Rusmarilin. 2006. Evaluasi Gizi dan Pengolahan Bahan Pangan Pedoman Praktikum. Medan : USU-Press.

Shahidi, F., dan C. Hong. 1991. Evaluation of Malonaldehyde as a Marker of Oxodative Rancidity in Meat Product. J.Food Biochem. 15: 97-105.

SNI-01-2729. 3-2006. Ikan Segar - Bagian 3. Penanganan dan Pengolahan. ICS 67.120.30

SNI-01-2891-1992. Cara Uji Makanan dan Minuman. Badan Standarisasi Nasional (BSN). Jakarta.
SNI-01-3182-1992 . Penentuan Kadar Air. UDC 663.1 : 543.71

Solarbesain, S. 2005. Pengaruh Jenis Ikan dan Lama Pengukusan Terhadap Mutu Ikan Presto. [Skripsi]. Fakultas Perikanan dan IImu Kelautan Unpatti, Ambon.

Suryana, D. 2012. Mengenal Teknologi. Bandung : Gramedia Pustaka Utama.

Tapotubun, A.M., E.E.E.M. Nanlohy, dan J.M. Louhenapessy. 2008. Efek Waktu Pemanasan Terhadap Mutu Presto Beberapa Jenis Ikan. Ichthyos. 7: 65-70.

Winarno, F.G. 1986. Kimia Pangan dan Gizi I. Jakarta : PT. Gramedia. 